\title{
Gender, narratives, and religious competition among the Sonjo of Tanzania
}

\section{Mika Vähäkangas ${ }^{1}$}

\begin{abstract}
For about sixty years, Christian mission has encountered the resistant Sonjo traditions, and much of the competition between religions has happened in the realm of narratives. Sonjo myths and stories change according to the religio-political needs, and Christians make use of stories or versions of myths that gain them leverage against the traditional religion. Christian mission attempts to utilize women's position as an argument for its benefit. Sonjo Christian women, finding themselves between two patriarchies, the traditional and the Christian, negotiate themselves additional moving space by positioning themselves usually in accordance to churches' positions but sometimes to the Sonjo traditions.
\end{abstract}

\section{Introduction}

This paper aims at discussing the ways in which Christian missionaries among the Sonjo, as well as Sonjo Christians argue, and could argue, in relation to gender, making use of missionary propaganda, popular narratives, myths and their versions among the Sonjo. What needs to be noted, right at the outset, that when dealing with the narratives, this paper will discuss male discourse related to gender. This is so because the narratives dealt with here belong to the male sphere of discourse. What is sought after is to look beyond the rhetoric and to assess the motives and agendas involved in this discourse. Most of the narratives dealt with contain the dimension of victimised women, even though the point of the narrative, at least originally, would not necessarily be that of presenting women as victims. The women's contribution to this discussion is more analytical and emerges in relation to missionary propaganda on Sonjo women's inferior role in their society.

The data used for this paper are the Sonjo myths and narratives recorded since the 1950's until the 1990's and the narratives I was able to collect in 2003 in group interviews conducted with the traditional leaders of Samunge village as well as local Christians and church workers. Another group interview with the leaders was conducted in 2009 but it did not produce any new narratives. Women's group discussion was conducted in $2009 .^{2}$ All of the interviews were conducted in Swahili in the form of common discussions between students of theology and the local people on

1 Prof Mika S. Vähäkangas is Professor in Mission Studies and Ecumenics at the Centre for Theology and Religious Studies, Lund University. He can be contacted at mika.vahakangas@teol.lu.se. 
study tours where I attended as a teacher. The discussions were thus not conducted in an imagined objective space but rather represent themselves as an interreligious dialogue or an encounter between persons considered to represent church hierarchy and the local Christians. In the group interviews, my role was seen definitely as representing the Lutheran church central hierarchy, even if I did not want to emphasise that conception. In the analysis, however, I attempt to distance myself from the ecclesiastic role and try to view the situation as an outsider both to the cultures and to the churches involved. The fact that during the recent six years I have no longer worked for the university of the Evangelical Lutheran Church in Tanzania has helped me to take the distance.

The Sonjo or Batemi are a Bantu-speaking people numbering about $30.000 .{ }^{3}$ Their economy is based on agriculture depending on irrigation in a semi-arid area in Northern Tanzania. Each of the five Sonjo villages forms an independent entity, and there were no political structures bringing together the Sonjo from different villages. Yet, they had, and still have, a strong sense of belonging together. A central dimension of this togetherness and their identity as the Sonjo is their religious heritage. ${ }^{4}$

The most notable political organization in each village is the group of the traditional leaders (singular mwenamijie, plural wenamijie), which controls the use of irrigation water, arable land and the trees. Because the whole economy is based on agriculture that is mostly possible only through irrigation, the power over water is the most valuable political power one can have. One of the interviewed leaders pointed out that the one controlling water controls the whole village. ${ }^{5}$

Lutheran mission among the Sonjo began in 1947, utilizing only African resources, and an American-led Roman Catholic mission entered the area in 1952. After some initial vitality, neither of the missions was very successful in terms of organizational growth, and Catholic presence is mostly limited to a hospital they run in Digodigo while the Lutheran church is a small and communally relatively insignificant entity active practically

2 On the religious encounter between Christianity and Sonjo traditions in a wider framework, see Vähäkangas 2008. Much of the argumentation of this article is found in the book, albeit with no contribution from Sonjo women which has helped me to improve the analysis.

3 This is a rough estimate based on previous estimates (Potkanski \& Adams 1998: 87; Schäfer 1999: 13). The government of Tanzania does not make statistics on ethnic belonging.

4 See Potkanski \& Adams 1998: 89. It has to be noted that the Sonjo, like most other African peoples, do not even have such a word as "religion" in their language, and thus all discussion on religion found in this paper is based on terminology and classification of cultural domains foreign to the Sonjo.

5 Peter Dudui fd. 07.11.2003: "Wenamijie ni wenye maji." Thus also Griffiths 1940: 17. See also Gray 1963: 61; Potkanski \& Adams 1998: 98. This connection between the wenamijie and water goes almost unchallenged because it is religiously based (Schäfer 1999: 229). 
Vähäkangas

only in Samunge, a village close to Digodigo. Lutheran services are occasionally held in other villages, too (Iversen 1984: 7-14). The third, and latest, arrival (1996) is the Pentecostal "Church of the 72", which is a small and vigorous community active in Digodigo.

The churches have not been able to keep a consistent record of their baptisms, and no statistics on church attendance is available. My rough estimate based on discussions with the churchmen responsible for the work among the Sonjo is that the number of baptized Sonjo is maximum $10 \%$ of the total Sonjo population. Regular church attendance among the ethnic Sonjo is just a fraction of a percent of the total population or just some few percents of the baptized Sonjo.

\section{The origin of Samunge spring and the death of a woman: A sacrifice, an accident or a gender conflict?}

In Samunge, there are two kinds of springs; one is cold and "profane" and the other is warm and holy. (Potkanski 1987: 209) The waters of the two springs mix at a lower point before reaching the irrigation system. The warm spring is ritually meaningful to the community and may not be approached by women in the fear of menstrual blood contaminating the spring. ${ }^{6}$

A Sonjo Lutheran pastor, now already deceased, Rev. Rong'ola, tells a story of how Ghambageu, the apotheosized cultural hero, expanded the Samunge fountain (obviously the warm one) and came to live in the village. Rong'ola's approach to Sonjo tradition is openly inculturational whereby he attempts to defend his cultural background as much as possible, interpreting it in a manner as compatible as possible to Christian faith.

When Ghambageu, coming from elsewhere, met with an inhabitant of Samunge with his friends, he complained that there was not enough water. Ghambageu gave them small stones, and instructed him to mix traditional beer when meeting with his pregnant sister, and to take it to the insufficient spring and throw a spear into the beer container, which would then improve in its water capacity. His friends began drinking beer, and dropped the stones all around, which resulted into several small springs in their village. The Samunge man, however, returned to his village with his stones. He took his pregnant sister, some beer and the small stones given by Ghambageu and went up the hill to the insufficient spring. Thereafter "he speared his [pregnant] sister and a lot of water came from there".

6 Peter Dudui fd. 08.11.2003. For further discussion on women's ban on the warm spring area see Vähäkangas 2008: 78-81.

7 “...akamchoma dada yake mkuki na maji mengi yakatoka sehemu hiyo." Rong'ola 1976: 19, the whole narration pp. 18-19. See also a closely resembling version in Schäfer 1999: 286-287. 
The story ends here. It is implied that the sister died, and the spring actually expanded. What can be seen in the end of the story is the inherent link between female fertility in the form of pregnancy and the spring water even in the hydraulic language when the expression lends itself to both amniotic fluid and increased spring water. It is possible that the sister serves as a sacrifice for gaining more water. Another interpretation is that as water rights are owned by the wenamijie, so are also the reproductive powers of women owned by men. Yet what seems to counteract that interpretation is that the woman is speared by her brother and not by her husband, who could be claimed to own the reproductive power of the woman. However, had the husband speared his own pregnant wife that would present a suicidal trait because that sacrifice would be a sacrifice of his own fertility through killing his own offspring. In this way, a brother might be taken as the representative of the male gender. Furthermore, a woman's dead father or grandfather are the ancestors controlling her sexual behaviour through punishing adultery with a difficult childbirth (Gray 1963: 123). Thus, even if the fertility of a woman is subjected to the husband and his lineage, the controlling role is still with the ancestors of the woman's own lineage. Even if the "ownership" of her fertility is elsewhere, the control of her sexuality is still in the hands of her paternal lineage, at least to an extent. Yet, the ownership of the fertility cannot traditionally be alienated from the mother because in divorce, the children follow the mother in remarriage to another family (Women's group interview 08.06.2009: 1) which means that a woman's fertility is in a way still linked with her paternal lineage. Even if it is never owned by the mother's paternal lineage, it is not severed from the mother.

An earlier version of this myth recorded by Finch clarifies that the sister died accidentally because the brother was aiming at the beer gourd carried by the sister, but the thrust was too strong (Finch 1957: 207-208). The outcome considering the spring was still the same. In this version, the death of the woman becomes a collateral damage from striving after more water. This version appeals more to common sense than Rong'ola's because it is common that men make women carry burdens. However, it does not make sense why the brother would thrust the spear at the gourd while it was still on the sister's back. Both versions have their logical twists because Rong'ola's version does not contain any reference to Ghambageu demanding the sacrifice even if a logic of sacrifice seems to be present. Accidental death following grave carelessness is more acceptable than a premeditated slaughter in the form of human sacrifice, so in this case Rong'ola, a Lutheran pastor, narrates a less humane version of the myth of the traditional religion than the one recorded by Finch.

The role of beer is vague. Through this drink men can be in contact with the gods as it is the "drink of the gods" (Schäfer 1999: 346) because of 
Vähäkangas

its intoxicating ability and possibly also because it is used as libation. ${ }^{8}$ Beer also belongs to social transactions, like when a woman's fertility is shifted from a lineage to another in marriage (Rong'ola 1976: 14).

There is yet a third competing narrative on the genesis of the Samunge spring. When the first two immigrants had arrived in Samunge, there was no water. One of them sent his sister to Belwa, the mythical abode of Ghambageu, where he gave her two stones to be used for creating springs. One fell on the way, resulting in the spring of Kisangiro, and she used the second one for Samunge. She claimed ownership to the spring, whereby the brother killed her. As a reminder, some stones close to the spring are still red. The two first Samunge male inhabitants began to cooperate in irrigating the fields. ${ }^{9}$

This version is more logical than the others in the sense of giving a rational explanation of the death of the woman. The reason for the death can either be a rationalisation made later, or else the less rational versions are degenerated accounts of this older one. At any rate, this version recorded by Gray, and Finch's version are the oldest ones. Gray's version points directly to the conflict between genders. Because water is the source of power, the women are excluded from administering it, in this case even by using violence. In a way, control over water would convey both of the major dimensions of fertility in the hands of women, because child bearing belongs to women naturally, and the fertility of the fields is completely dependent on the irrigation water. However, male domination over water needs justification and it is here that Ghambageu becomes useful. He can be described in many ways the guarantor of male privilegies. If the power by which the spring came about originated from Ghambageu, then the woman's claim to the spring was not legitimate. One can support the male domination over water also symbolically, considering water as representative of semen. This kind of discourse of water referring to semen was actually indirectly proposed by Christian missionaries, who interpreted the Sonjo expression of blessing as "opening the sluices of Belwa" as a reference to a sexual orgy (P1, P3 fd. 07.11.2003). However, this symbolical line of argumentation may not be considered as overly convincing.

The theme of the gender-conflict is not rare in East Africa. The Gikuyu of Kenya have a myth of how the women once were the rulers very despotic ones. Men eventually managed to gain liberation, and since then they have been very careful not to let power slip from their hands. Among the Meru and the Chagga of Tanzania, there is a taboo of women being present in the slaughtering of cattle. When I have discussed the issue over the years, the interpretation for that taboo is that if women would learn

8 On libation to the ancestors, see Rong'ola 1976: 47; Gray 1963: 123.

9 Gray 1963: 103. Reference to original inhabitants refers also to wenamijie who are believed to be their direct descendants with a special relationship to God. Wenamijie Samunge 08.06.2009, 1 . 
how to slaughter, they would be able to take cattle and prepare feasts of their own, thus ridding men of this resource.

At any rate, none of the recorded versions on the origin of the Samunge spring seems to be actively used for religious competition. The myth does not provide clear tactical advantage to any of the two religions. It would have, however, plenty of potential for gender-related argumentation. However, because this argumentation would not provide any leverage for Christianity, it is left unused.

\section{Mase as cheating of women}

Christianity is at the moment the only religious entity in Samunge that can challenge the socio-religious status quo. The competition between the two worldviews takes place to a great extent in the sphere of myths and narratives. If the Sonjo ruling class uses selected Ghambageu myths to consolidate its position, the Christian leaders and some of their flock choose such myths from the Ghambageu corpus that can be used to question the validity of the present wenamijie's interpretation of Ghambageu. ${ }^{10}$ Christians, having a Messiah of their own, cannot let the Sonjo divine-human saviour go unchallenged. Water issues can be understood as secular and not crucial by the Christians, and left to the wenamijie, but in the case of Ghambageu there is a headlong collision between the religions.

The subversive myths can be divided roughly into two categories. One category deals with Mase and revolves around gender and sex. These myths are such that they would never have been approved of by the wenamijie. ${ }^{11}$ The second one consists of old myths which have belonged to the Ghambageu corpus at least for some time, but which now have been left aside by the wenamijie but can be used to discredit Ghambageu.

The first cluster of myths revolves around the Mase feast, which is the most important Sonjo festivity, at least according to the Christian pastors. The wenamijie told us that Mase is a feast of commemorating Ghambageu's death or departure (Peter Dudui fd. 07.11.2003). They were not very willing to reveal much about the feast, and the feast has been surrounded by secrecy for a long time. However, Gray (1963: 133-117) gives a rather detailed account of it as it took place about sixty years ago whereas Fr. Donovan (2011, 144-146) has also made some observations. Some additional information has been gathered from Rev. Gabriel Kimirei.

In the beginning of Mase and during the festival there are the sounds of horns that are claimed to be Ghambageu's sound. ${ }^{12}$ Women and children are not supposed to know that it is produced by horns, whereas the initiated

\footnotetext{
${ }^{10}$ For a more covering analysis of the myths, see Vähäkangas 2008.

${ }^{11}$ Here, I consider that when wenamijie recount or have recounted at some point a certain myth, it has been approved by them.
} 
men know its origin. That the priests and leaders of the traditional religion blow the horns looks like a public secret, even if the Sonjo would not agree to tell you so. ${ }^{13}$ The existence of the horn(s) is mentioned in several studies, and this fact has been recorded from among the Sonjo. It would be remarkable if initiated men would have been able to keep the secret from women and children if they have told it to the outsiders. Gray (1963: 114) reports that some of the early Sonjo Lutheran converts thought that the sound was that of Ghambageu, whom they said was the devil. Thus, in their eyes, Mase would be basically worship of the devil. However, if Gray's interviewees really believed so and if they were initiated men, this would imply that even some of the men do not know about the horn. A more plausible explanation for Gray's Christian interviewees' answer would be that they felt the pressures of both Christian and Sonjo communities: the Sonjo expected them not to reveal the secret whereas the Christians expected them to condemn all traditional religion as devilish. Their answer suited both of the parties.

One of the strategies of early Lutheran missionaries in 1949 was to bring a trumpet band from Kilimanjaro to Sonjo. It was thought that seeing a trumpet, it would dawn to the ignorant Sonjo that the sound in Mase is fabricated. ${ }^{14}$ This approach was of relatively little help in the long run.

Christians attempt to destabilize Ghambageu cult through narrating a story which describes the origin of the horn. Once upon time, in Samunge there was a horn that was used by the community for digging up different edible roots in the bush. The horn, hanging in a tree outside the village got worn in use, and a hole developed in its tip. One day a terrifying noise came from outside the village, and frightened men in arms rushed to fight this enemy only to find out that the horn gave this sound being blown by wind. The men did not want to seem ridiculous in the women's eyes. Therefore, they decided to make up an explanation that Ghambageu making the noise has come back with many good blessings. The women believed them, and the horn became the men's secret. ${ }^{15}$

12 Donovan 2011: 144-145. According to Schäfer (1999: 170), Gray made an essential mistake in counting the sound as that of Ghambageu because that interpretation simplifies the picture too much. For Schäfer, the sound is that of Ghambageu, but not only his personal voice but a voice representing the transcendence. In Schäfer's interpretation, the voice itself also becomes a divine power.

13 Gray 1963: 114, 122; interview with Solomon Isaya 12.06.2005; interview with Gabriel Kimirei 21.06.2005; Namjogo 1996: 24, 40. Namjogo is a Lutheran pastor from Sonjo background, but he is not positioned in the Sonjo area. Solomon Isaya thinks that women and children do not actually know about the horn.

14 Namjogo 1996: 24-25 referring to a letter by the missionaries from 1949.

15 P3 fd. 07.11.2003. Schäfer (1999: 171-172) has recorded a similar story and mentions that there is also a version where the horn was found in a termite hole, the termites having eaten it open from the tip. 
This myth not only implies that Ghambageu's annual visit is a forgery but also that it is a conspiracy against the women. Men are shown in a dubious light, first overreacting to the sound and then covering the ridiculous reaction with a deceitful action. Thus, they turn their comical behaviour and fear of the women's ridicule into a means of controlling the women. This story challenges the whole credibility and legitimacy of Ghambageu cult by pointing out that the root of the cult is a scam.

In many cultures horn serves as one of the traditional symbols of masculine virility and thus it suits as a "secret" symbol of male power through Ghambageu in Sonjo society. Sometimes the horn has been described as a "male" horn, which could be understood as a reference to the male character of that material symbol. Rong'ola, however, maintained that there were actually two horns and that Mase was not originally a feast of Ghambageu visiting the Sonjo but rather of Egantwalu and Nankone, a male and a female god, visiting the villages. These gods were a couple, and the bigger horn would be the sound of Egantwalu and the smaller one would be that of his wife Nankone (Rong'ola 1976: 27, 28, 45, 50). This could also explain the description of a horn as "male", referring to Egantwalu. ${ }^{16}$ In addition to these two, Schäfer (1999: 170) also mentions yet two other horns, namely Karawadeda and Egansigilar. Karawadeda is a child of Nankone, and Egansigilar is another male divinity.

According to the Sonjo beliefs, in Mase, Ghambageu sits in a hut and listens to questions and answers them in an eerie voice. An elderly man acts as the interpreter of the divine sound. Often the problem about which people come to get advice is childlessness or other marital issues. Some Christians maintain that Ghambageu is not in the hut but rather men who wait for women to come to ask advice about marital problems. Ghambageu's message is clear: women should obey their husbands. ${ }^{17}$

If Christians present this counselling in a dubious light, the wenamijie see it in a quite different way. They told us with obvious pride that even a mzungu (Swahili: a European or an American) had come with his wife to get help, and the wife gave birth later (John Mengo fd. 07.11.2003). Unlike Christian interviewees, they did not point out that the counselees would be women. This efficacy of the Mase consultation is not denied even by Christians: a former Tanzanian Lutheran missionary, Rev. Isaya, pointed out that many childless couples actually do get help from visiting Mase, but he could not explain how Mase could help them to have children (Interview with Solomon Isaya 12.06.2005). Also, the Maasai have a great respect for

${ }^{16}$ Watschinger (ca. 1982: 114) interprets Egantwalu as the name of the horn.

${ }^{17}$ P2 fd. 07.11.2003; Watschinger ca. 1982: 114. See also Schäfer 1999: 174. Thus also Fr. Donovan, albeit he points out that also the Christians control ordinary people and especially women in a similar way, too. He refers to Christian clericalist tendencies (Donovan 2011: 145-146). 
Ghambageu in Mase and come to get help especially with childlessness, bringing goats and today also cattle as payment (Gray 1963: 117; 1966: 55; P1 fd. 07.11.2003; Schäfer 1999: 174).

In the Christian description of Mase counselling as a form of deceit, Sonjo men are depicted as crooked persons who do not hesitate to use deceit in order to keep their superior position over women. The power of Christian argumentation is rendered weaker through the fact that the Christians do not always deny the efficacy of Mase in solving the problem of childlessness.

\section{Women who discovered the Mase secret}

Another subversive story connected to Mase and the men's secret tells us how a woman got to know the secret. It is narrated by Christians, as can be expected. A woman was walking in the forest during Mase and came across the secret horn. When the men found this out, she was killed. Yet another woman happened to see the horn. However, she was very popular, and the men did not want to kill her. She was made swear not to tell anyone about the secret, and made an honorary man by all the men in turn spitting and blowing the horn into her vagina (P1 fd. 07.11.2003).

Rong'ola tells a less detailed version of the same story stating the name of the woman to be Nankone. She eventually became the great female goddess of the Sonjo (Rong'ola 1976: 27). A version recorded by Schäfer also describes how Nankone saw Ghambageu dealing with the horns. When he wanted to kill her, she called for Sonjo young warriors to help. As a result, she shared the secret, and were she to tell it to an outsider, she would lose her life (Schäfer 1999: 183).

The point of this story is to claim that there is indeed no men's secret but rather a brutal oppression based on a faked hierarchy of knowledge. The difference between the fates of the women can also be seen as a reference to the arbitrary nature of the ruling men's attitude. Additionally, Rong'ola's account of the apotheosis of the woman getting to know the secret is a highly subversive story, because in it the woman's knowledge lifts her above the men.

In all of the stories with their versions, the horn serves as the material symbol of male oppression and deceit over the women. Hereby, the whole Ghambageu cult is deprived of its legitimacy and implicitly compared to the genuinely religious Christianity which also appreciates women. ${ }^{18}$ But what would then keep the traditional religion intact? According to the Christian argumentation, it is only brute force.

18 This attitude was already visible at a very early stage of the Lutheran mission among the Sonjo. See, for example, Danielson (1959: 24), who comments on the Sonjo religious taboo against men using a hoe: "This looks like a taboo invented by the men!" This contains a double message; this religion is invented by men (and thus it is not from God), and it is used by the male gender to oppress the women. 
All the initiated Sonjo men have sworn to keep the secret of the Mase horn in a kind of a blood pact (P1 fd. 07.11.2003; Donovan 2011:144-145). Watschinger maintains that the first two Roman Catholic catechists of Sonjo background were actually poisoned because they were suspected of having revealed Sonjo secrets (Watschinger ca. 1982: 114). Both the Sonjo and the Christians emphasise that keeping the secret of the Mase horns is extremely serious business. This is naturally due to differing motives. The wenamijie want to warn the people about how dangerous it is to break the vow of silence, interpreting all possible occasions of death of people suspected of breaking that vow as results of the curse they have brought upon themselves. From the Christian point of view, there is no curse but rather an oppressive system in which a deviant person is mercilessly killed. In this way, the Sonjo status quo is further put into question.

However, even if there is a punishment aspect, real or imagined, connected to the keeping of the secret, the fact that the sound is produced does not necessarily rid it of all credibility even in the eyes of the ones involved. It can also be interpreted symbolically. Schäfer (1999: 173) argues that the case of the horns is not only a question of cynical legitimising of male domination but that men really believe in the divine power in the horns.

It seems that the myths related to the Mase horn in Christian propaganda are made to point out to the Sonjo women as cheated and downtrodden. However, the point that there are, or were, two horns, out of which the other represented a female divinity, is a possibly empowering view. In order to be able to make use of this myth in an empowering sense, the Christian concept of God would need to get past its patriarchal character. In Tanzanian academic theology this has been done to an extent, but it does not necessarily have any impact on the parish level (See Nyamiti 1981). Also the myth telling us how Nankone became a deity through a secret knowledge of the horn could possibly open avenues for critical and empowering discussions on the role of knowledge and power in religion. Again, this kind of discussion might require a more critical and open atmosphere than actually is available in the churches.

At any rate, the Christian narrations about the horn display openly the way in which religious controversies are carried out in the sphere of narratives. There are also direct narrative offensives against Ghambageu.

\section{Ghambageu could not control his wife}

Ghambageu is under direct attack in the story that depicts him as incapable of dealing with his wife. He had to move to Kisangiro from Samunge because the people of Samunge ridiculed him, his wife having had run away with the Dorobo (a despised hunter-gatherer group) (P3 fd. 07.11.2003). "Ghambageu" is explained to mean "a man more than the other men" (Peter 
Dudui fd. 07.11.2003) or "the leader of his people". ${ }^{19}$ Therefore, this story undermines effectively the credibility of the guarantor of male wenamijie dominance by questioning Ghambageu's authority even over his wife.

However, in another version Ghambageu has supernatural abilities, and her cheating him with the Dorobo man is known by him. While letting it happen, he kills all of the Dorobos near Samunge. Yet the wife and her lover run away unharmed (Schäfer 1999: 293-294).

Even the second version describes Ghambageu's supernatural powers as limited because he cannot control his wife nor can he destroy her and her lover (Schäfer 1999: 296). What is interesting that in a culture that values marriage and reproduction very highly (see e.g. Rong'ola 1976: 14), the wenamijie maintain today that Ghambageu would never have married (Peter Dudui fd. 07.11.2003). Yet, the oldest recorded version on the life of Ghambageu claims that he was married. This version was recounted by Simeon Ndula, an early Sonjo convert to Christianity who worked for the colonial government. His later version, in which there are some elements that can be interpreted as apologetics of Ghambageu cult, Ghambageu is still presented as a married man (Ndula, Mavalla \& Fosbrooke 1955: 40). Rong'ola (1976: 16) gives us the names of Ghambageu's two wives, and there is also another account that describes him having wives both in Samunge and Kisangiro (Schäfer 1999: 294-295).

One possible reason for the wenamijie's rejection of the idea of Ghambageu's marriage could be that if his marriage is not discussed or if it is denied, these stories about his wife's flight and insubordination can be dismissed as impossible. Furthermore, the wenamijie told us about Ghambageu's celibacy when defending Ghambageu in front of Christians who would not be offended of someone's celibacy, unlike some traditionalists might be. There is also the possibility that Ghambageu's celibacy might have been used only in an apology to outsiders. The fact that there are no known descendants of Ghambageu among the Sonjo may also have contributed to this conclusion.

This development of denying his marriage seems to be quite recent, because Ndula and Rong'ola, as Christian as they might have been, both seem to have no intention of dishonouring Ghambageu. Rong'ola shows a strong tendency of denying his divinity but still giving him much honour in a manner that resembles a Roman Catholic inculturation approach rather than a Lutheran negative view on Sonjo religion..$^{20}$ Actually, this myth on the fleeing of Ghambageu's wife has been recorded only very recently and one may even

${ }^{19}$ Rong'ola 1976: 18. Schäfer (1999: 280) maintains that the name Ghambageu means basically "that which is in a constant change".

${ }^{20}$ One needs to remember that this kind of negativity was not the only Lutheran approach but even in the home areas of the Tanzanian Lutheran missionaries one could find quite appreciative missionaries, like Bruno Gutmann in Kilimanjaro. See e.g. Jaeschke 1985. 
question whether it existed when Rong'ola wrote his research paper in the 1970's. In denying Ghambageu's marriage, the wenamijie can still use him to support male domination even if his usefulness may be negatively affected. At least there would be no possibility of referring to Ghambageu's marriage as an example to the Sonjo of today.

The above described story of Ghambageu's wife running away is potentially dangerous to male supremacy because of featuring a woman who makes her own decisions even though her husband is the greatest of men. As such, this kind of action breaks against the patriarchal expectations of both of the religions and is narrated by Christians because it involves only the other party. It could be understood as the Sonjo Da Vinci code, so to speak. However, were the actions of Ghambageu's wife accepted on a more general level, women would be granted such freedoms that Christianity in Tanzania does not accept.

\section{Women: victims of human trafficking or independent subjects?}

All of the three churches active among the Sonjo reject the idea of divorce and remarriage. Because of this they cannot use the myth on Ghambagau's wife in a constructive way to build up women's self-esteem and to empower them, if they wanted to or not. Marriage, in which a young woman traditionally often ended in without her consent is thus a cul-de-sac when seen in the light of Tanzanian Christian ethics. However, the interviewed Sonjo Christian women pointed out, that involuntary marriages belong to the past, and the youth of today have a much greater say in the choice of the marriage partner than in the past (Women's group interview 08.06.2009: 2-3).

Sonjo culture accepts divorce and remarriage, and this occurs frequently (Women's group interview 08.06.2009: 5). A woman, after first having been married, remains married even in the case of being widowed or divorced. In the case of divorce, a new marriage arrangement must have been planned before the divorce can take place. A woman may be active in initiating such a process. It is, however, controlled by men because her husband must agree upon the divorce and she must find a new husband, who will pay the present husband the bride price (Gray 1968; Women's group interview 08.06.2009: 1-5). Traditionally, children always followed their mother in cases of remarriage (Gray 1968: 266-269; Women's group interview 08.06.2009: 1). Today, the situation has begun to change - the interviewed women called it "being corrected", apparently to be in line with the strongly patrilineal "Christian" cultures of the missionaries (e.g. Chagga, Meru, Pare, Arusha). Some men do not want the new wife to come with her children whereas some men whose wives are leaving do not want to let the children go because of affection to them. This change seems to begin in the families closest to Christianity (Women's group interview 
08.06.2009: 1). This has probably to do with the increasing modernisation of the family structures where children are decreasingly agricultural work force, i.e. a financial asset, but rather a financial burden with all their needs like schooling. Furthermore, a great number of male heirs can also be seen as a negative thing because it leads to the splintering of the inheritance (See Schäfer 1999: 55). Therefore, the question of affection becomes more topical also vis-à-vis men while in the past one may have seen it mostly as an issue between the mother and the children.

Christian mission has described the Sonjo marriage, divorce and remarriage system with its rotating bride price as trade on humans - selling and buying of women and children. ${ }^{21}$ The point of this is, on one hand, to emphasise how miserable the situation of the women is in the Sonjo community and, on the other hand, how immoral the Sonjo are. Also among Roman Catholics, the position of women is presented as a miserable one and their idea of marriage as "very fluid" (Donovan 2011: 136, 149, 180). However, while seemingly pro-women in the argumentation the way the myth on Ghambageu's wife's fleeing is used by the Christians actually fortifies the patriarchal logic that considers a wife as a property of the husband. When pointing out that Ghambageu was not able to control his wife, the Christians actually present the patriarchal power structure as normal or normative, thus strengthening it. This they do probably subconsciously, male supremacy being the norm. Thereby, a woman is not seen as quite a full subject even among the Christians. The Christian women point out, however, that in Sonjo tradition they have no say in common matters whereas in the church they are autonomous in women's groups (Women's group interview 08.06.2009: 1). But, are the Christians correct in accusing the Sonjo men of human trafficking?

Gray, an anthropologist, has pondered whether the Sonjo have a bride price or bride wealth. He comes to the conclusion that the Sonjo actually do have a bride price which is paid during the betrothal period or marriage, always in full; partial payments are not refunded should something go wrong, such as if the wife(-to-be) dies. ${ }^{22}$ In the case of the death of the husband, levirate is applied, the inheritor being the eldest surviving brother of the deceased (Gray 1968: 265-266). In remarriage the new husband pays an agreed bride price to the former husband, and additionally a fixed fee to the wenamijie. In case of the death of the husband or fiancé, if the brother does not want to marry the widow, he can sell her to another man, who will pay a reduced price since the deceased will be the husband of this woman in

${ }^{21}$ See Nathan, Eliufoo \& Salema 1952: 7; Danielson 1959: 21; Parsalaw 1999: 351; Mkutano Mkuu wa kumi na moja wa Dayosisi ya Kaskazini 1966: 83 quoted in Iversen 1984: 15.

22 Gray 1968: 263-265; discussion on the "selling of wives and children", see also Iversen 1984: 15-16. It is also interesting that in the creation myth recorded by Gray (1963: 98), there is a reference to woman as the property of man. 
the afterlife because they had not divorced. The "reselling price" of a woman depends on her qualities. ${ }^{23}$ Gray expresses quite clearly how he interprets this system:

A husband exchanges his wife rights with another man for a sum of goats. It is convenient to say that he "sells" his wife, because the form of the transaction is basically same as those in which he exchanges or sells other goods. Thus a young wife is treated economically as a commodity (Gray 1968: 267).

The Christian women were quite clear about the terminology, pointing out that in the case of the first marriage, the language used is not economical there is no implication of buying and selling. When it comes to the remarriage business, the man divorcing his wife says "namta" ("I sell her" in Sonjo) and the new husband uses the term "namkwa" (I buy her" in Sonjo) (Women's group interview 08.06.2009: 1-2). From this point of view, especially taking into account the women's strong emphasis on how the bride price constitutes the relationship between the families of the bride and the groom, one could as well maintain that in the case of the first marriage, there is bride wealth. In remarriage, it would logically and semantically (at least concerning the verbs) turn into bride price.

The late Lutheran inculturating pastor Rong'ola attacks the missionary propaganda against the bride price by rejecting the idea of buying and selling of wives and notes that "some people ... say that he sells his wife but that is actually the price he brought forward to betroth his spouse..." ${ }^{24}$ What is noteworthy is that he is dependent on the Sonjo usage of financial terminology, like "bei" (price) for bride price/wealth and interestingly enough, the fiancée is called "mali" (property). ${ }^{25}$ His terminology points in quite other dimension than his argumentation. The Samunge wenamijie refer to women as a kind of property when emphasising that even if women cannot participate in decision making they are protecting the women the way they protect the environment (Wenamijie group interview 08.06.2009).

Rong'ola's argument seems to be that there is no question of buying and selling inasmuch as the price remains the same and thus there is no profit made by the divorcing husband. Yet even that possible argument does not seem credible because elsewhere he describes how girls that became

${ }^{23}$ Gray 1968: 266-269. On the price reduction for a widow and the couple continuing to be spouses in the afterlife, see also Rong'ola 1976: 87.

${ }^{24}$ Rong'ola 1976: 72: “...watu wengine ... wanasema kwamba anauza mke kumbe ndiyo bei ambayo alichukua kwa kuchumbia huyo mchumba wake..."

${ }^{25}$ Rong'ola 1976: 83: "Maana Watemi wao humchumbia mtoto mdogo na kulipa mahari yote kuonyesha kuwa huyo ni mali yangu." ("Thus, the Sonjo betroth a small child and pay the whole bridewealth/price to show that this [girl] is my property.") Schäfer (1999: $63,86)$ maintains that there is no selling and buying of wives among the Sonjo but rather it is a matter of an exchange of gifts, which also contains an economic dimension. 
pregnant before female genital mutilation could be sold to the Maasai. ${ }^{26}$ It is hardly conceivable that in dealings with the Maasai, the Sonjos' archenemies, a Sonjo would resist a possible financial gain if the Maasai were ready to pay more for the girl than he originally did. Also in the case when there is no willing new husband available but the divorce is sought after, the wife can be "sold" to the Maasai. The Samunge women all knew of such a case (Women's group interview 08.06.2009: 2).

\section{Does Sonjo bride price oppress women?}

Christian missionary propaganda takes this buying and selling of wives or wife rights as proof that the traditional Sonjo oppress women, obviously more than other societies, or at least Christian communities (E.g. Watschinger ca. 1982: 112-113, 129). In the women's group discussion, a student of foreign background posed a question about the women's role in the church. The former assistant to the bishop of the Lutheran diocese, and a pastor with regular missionary visits in the area, Rev. Kimirei, translated, making the question very leading:

...do you women have the possibility of meeting in your assemblies among yourselves to discuss these issues that place woman in an inferior position to the extent that you look like market commodities in a man's hands, such that he may use or dispose of as he wishes? ${ }^{27}$

The women's reaction was startling in front of this not only very respected church leader, well educated and of advanced age, but also a guest who are usually treated in utmost respect. Even if the tone of the women was neutral, their point was to openly reject the official ecclesiastical position that was being imposed on them. The elderly pastor implied namely that the women would be far better off in the Christian system rejecting divorces altogether. The women took the point of view of a compassionate parent in their argumentation - probably to lift up the hierarchical level of the discussion closer to the pastor:

Your child has got married. Now (s)he is in quarrels with his wife or her husband. So, wouldn't your option be that this child should not be tormented but that rather (s)he should find him/herself a new spouse? So that (s)he

${ }^{26}$ Rong'ola 1976: 84: “... hao wasichana waliweza kuozwa [sic] kwa watu wengine hasa Masai." (“... those girls [who had become pregnant before female genital mutilation] could be sold to other people, especially to the Maasai.")

${ }^{27}$ Rev. Kimirei in women's group interview 08.06.2009: 4: “...ninyi akina mama mna nafasi ya kukutana katika mikutano yenu wenyewe mkazungumza mambo hayo ambayo yanamweka mwanamke katika hali ya chini kiasi kwamba ninyi mnaonekana kama ni vyombo vya biashara au chombo mkononi mwa mwanamume kutumia kuondoa anavyotaka?". 
would get the freedom to be married and to live there with her wife or with his husband? It must be painful because why should my child be tormented... ${ }^{28}$

The argument calls for common sense and compassion for the partners that have ended up in an unsatisfactory marriage. The women do not consider the Tanzanian churches solution based on the Bible (Mt 5: 32; 19:6,9) as humane. Therefore, they seem to imply that even if the ecclesiastic position is based on the text of the Bible, allowance for divorce and remarriage is more in line with the Christian ethos. The continuation of the reaction becomes almost mocking in tone - but yet within the limits of a friendly conversation. The women pointed out that they had never organised a meeting with the agenda

...let's get rid of the bride price... And anyhow, it wouldn't work because what should we propose instead? Should we tell the [male] leaders/elders that let us not be married, or that we should go for freee [long vowel denoting ridicule] or what should we do $?^{29}$

The women point out that they are not in the position of challenging the bride price system. There is probably the implication that they lack the political power to do so. However, the heavier argument is that they would not have a better solution to propose. Then follows a more analytical assessment of the young woman's situation:

A child can live with an adolescent without bride price. She can continue to give birth to children with him, to give birth with him [repetition referring to continuous activity] and then, one day, he gets another girl and leaves your one. What do you demand? Nothing. Because of this, it is better that if a girl agrees to marry, she should be married so that you'd get as a parent, what? That bride price. [MV:] Bride price helps to create... [Women in unison:] Relationship! [The woman continues alone:] And respect, too. That father respects his wife, but the wife fears her husband because she has got married..$^{30}$

${ }^{28}$ Women's group interview 08.06.2009: 4: "Mtoto wako umemwolea. Sasa akaja kughorofshana na mke wake au mume wake. Si utakuwa ni uamuzi kwamba huyu mtoto wangu hatateseka wakati umtafutie mume mwingine? Ili apate uhuru kuolewa na kwa kukaa kule kwa mke wake au kwa mume wake? Hiyo lazima iume kwa sababu mtoto wangu kwa nini ateseke..."

${ }^{29}$ Women's group interview 08.06.2009: 4: “...'tupinge mambo hayo ya mahari' ... Na hata hivyo haitawezekana kwa sababu sasa tutasemaje sasa? Tutawaambia hawa wazee kwamba tuache tuolewe, twende bureee au tufanyije?"

${ }^{30}$ Women's group interview 08.06.2009: 4: “Mtoto anaweza kuishi na kijana bila kulipa mahari. Akaendelea kuzaa nayee, kuzaa nayee, ikatokea siku moja atampata msichana mwingine akamwacha yule wa kwako. Utadai nini? Hakuna. Kwa hiyo basi, ni bora kama msichana anakubali kuolewa, aolewe ili uwe mzazi upewe nini? Ile mahari (MV: Mahari inasaidia kuleta ... Naiset: Uhusiano! Kwa mke na mume.). Heshima pia. Yule baba anamheshimu mke wake, lakini mke atamwogopa yule bwana wake kwa sababu ameshaolewa." Here the word "kuogopa/to fear" should be interpreted as fear in the sense 
Thus, the women point out that the bride price is actually there to strengthen the marriage, and in that way it protects the wife who in that context is the more vulnerable of the two parties. The central concept here is heshima which means respect, dignity, integrity, respectability and even responsibility. What is noteworthy is that the persons cohabiting are referred to as children, girls and adolescents even if in the example the "girl" would have given birth to several children. Maturity, uzima, is the concept behind the designation of the cohabitants as children. They are not mature because they do not follow the community's norms thereby weakening the community from within. Uzima is much more than a prescribed age, and actually can be translated also as fullness, salvation or completeness. In this case, a full human being is one that is in good relations to the families involved, and the community at large. As a result, this person gains the respect of the community, and can subsequently be considered as a full member, a mature person, in the community. (S)he can be considered such because of having heshima.

This background helps to understand that bride price cannot be a simple financial transaction but it involves families and regulates relationships between them. Additionally, because the bride price is paid to several people, and it usually is collected not only from the groom but also his relatives and friends contribute, even divorce cannot be a private and rash matter but it involves the larger community. And finally, the divorce does not rob the woman of her dignity or integrity - the bride price stands as a guarantee for her dignity. It shows that the new husband respects her so much that he takes the pain to pay or collect the financial resources needed for marrying her.

What struck me in the discussion was how open and determined the women were. They were also in a very explicit agreement which was manifested - in addition to agreeing murmurs and occasional general discussion in Sonjo - in the interruption of my clarifying question as a group. All of the women answered my question before I had even formulated it.

The Sonjo bride price system where the whole of the price is returned to the male divorcee (or his family) can even be interpreted as an advantage to women. Rev. Rong'ola (1976: 83) namely argues that among the Chagga of Kilimanjaro, the ethnic group of many of the Lutheran missionaries, the bride price is not returned in full in case of divorce. Therefore, there is an economic pressure to keep an unsatisfactory marriage going, no matter how painful it is to the spouses. Additionally, even if the ecclesiastic argument in favour of only a partial return of the bride price might be that it stabilizes the marriages, it actually narrows the possibilities of a woman getting out of an oppressive relationship whereas the Sonjo system stabilises the marriage but at the same time leaves the backdoor open for divorce.

of respect and obedience rather than terror. 
In a Christian setting where divorce is out of the question, the women do not even have the possibility of trying to find another man. Even in cases of obvious crimes against the national law of Tanzania, such as domestic violence, the Christian pastors tend just to counsel the victimised wife to persevere in the oppressive situation in the hope of a transcendental reward (A. Vähäkangas 2004: 42).

Furthermore, if a divorce takes place, in many patrilinear predominantly Christian communities, such as among the Chagga, it is the husband who claims the rights to the children, and the mother has hardly any say in this. As seen, this is different among the Sonjo. This could be interpreted so that the position of a mother is stronger among the Sonjo than among the Chagga, because in the case of a divorce the husband does not only lose his wife but also (some of) his heirs.

In the final analysis the fact that a woman can initiate a divorce and that traditionally would not mean losing her children gives women more freedom to act in the community than would be the case in the Christian communities banning divorce. These Christian communities often combine the ban on divorce with patriarchal traditions both from Africa and Europe. ${ }^{31}$ Yet, the possibility to initiate divorce does not implicate that a Sonjo woman would be completely free to make her decisions or equal to the husband, far from that.

Thus, one may conclude that in the accusations about the Sonjo, it is in some sense true that women and children are bought and sold. ${ }^{32}$ However, this conclusion does not necessarily imply that the situation of a woman in marriage is any weaker among the Sonjo than in many other communities in Tanzania, including Christian ones, possibly even the contrary, depending on the community of comparison. Furthermore, I have heard even a Lutheran pastor of Haya background arguing publicly in a church that he has the right to dominate his wife because he has "bought" her, referring obviously to Haya "bridewealth". Thus, the idea of women as their husbands' property is not entirely absent from Christian communities, either.

What is interesting in this debate is that the position of poor young men is not usually taken into account in the above debate on bride-price. When marrying requires substantial economic resources, young men of poor families tend to be marginalised while rich men acquire for themselves several wives. The problem of poor young men is only mentioned without a comment by Lutheran pastor Bumija Mshana (1976: 44). The reason for this

${ }^{31}$ Mercy Amba Oduyoye (1995: 80, 172, 214) argues that in colonialism and Christian mission in Africa, African men found their ally in reinforcing patriarchy. She discusses the issue from a West African point of view, but similar developments can be traced in East Africa, as well (see M. Vähäkangas 2003: 479-482).

32 This is agreed by Samunge women on a semantical level Women's group interview 08.06.2009: 1 
silence might be that this argument meets not only Sonjo but also most other Tanzanian marriage traditions in one way or another. In this case, the missionary propaganda would criticise one's own cultural background, as well. Furthermore, the churches seem to consider themselves more often as champions of the women's rights rather than the case of the poor. Finally, the Sonjo may, after all, represent a more humane approach to this issue due to the relatively low degree of commercialization of their society. When I posed the women a question whether a man able to pay a greater bride price would be preferred, the women were clearly dismissive of such a commercial setup of the question and maintained that one might be able to marry even without property. ${ }^{33}$ The Samunge wenamijie purported that even if an outsider were willing to settle among them and marry, the community would raise him the bride price (Wenamijie group interview 08.06.2009).

\section{Churches - champions of women?}

Divorce and remarriage as trading on women is presented by the Christians as oppression of women, and that trade as divorce is presented as immorality. The theme of sexual immorality in connection to ATRs belongs to the standard imagery of Christian missionary expansion in Africa south of the Sahara. This has usually been in connection to the light or scarce clothing of Africans in the past in their adaptation to the climate. Even if initially this was a matter of a cultural encounter between a Western (Victorian or the like) dress code and an African traditional dress code, it has to be remembered that the early Chagga and Meru missionaries and later Tanzanian church workers to the Sonjo even today largely share the old Western dress code. ${ }^{34}$ Also, the Sonjo have traditionally been very lightly clad, and this might have affected the early church workers' estimation of the Sonjo as sexually loose people.

Polygyny used to be the other issue that was counted as proof of African cultures' sexual laxity, but in case of the Sonjo, surprisingly, it has not been discussed much. ${ }^{35}$ In addition, loose sexual behaviour has been one

${ }^{33}$ Women's group interview 08.06.2009: 3. A story tells how monster Ndirimasi married an unwilling Sonjo girl by giving her father a great bride price, intending eventually to devour the poor bride. The father's greed, however, is shown in a negative light very much in the same line as the women's moral anger against bride wealth as a means of gaining fortune. The story can be found in Schäfer 1999: 361-367.

${ }^{34}$ Watschinger (ca. 1982: 112) points out with humour that the Sonjo actually invented the miniskirt, thus indicating that in the meantime the western dress code has undergone radical changes.

35 According to Schäfer (1999: 54) and Rong'ola (1976: 71-72) polygyny is a relatively common practice among the Sonjo whereas Gray (1968: 265) maintains that it is a rare phenomenon. Interestingly enough, Lutheran pastor Rong'ola sees no problem in polygyny. Among the Sonjo, the husband does not need the consent of the first wife to marry yet another one (Schäfer 1999: 54), which is a fact that Christian argumentation has not taken up. 
of the standard accusations made by Western missionaries of the African traditionalists. Thus, Lutherans and Catholics have pointed out that Sonjo spouses are not faithful to each other. ${ }^{36}$

As to the Sonjo men's oppression of women, one should note that all the pastors that have ever worked among the Sonjo have been men. The Roman Catholic Church and the Tanzania Assemblies of God do not ordain women for the ministry, whereas the Lutheran church does. Yet, there is neither a female bishop nor a female assistant to the bishop in the twenty Lutheran dioceses in Tanzania, and it seems likely that there will be none in the near future. Also, the gender ratio in other leading positions of that church is overwhelmingly male. ${ }^{37}$ The Tanzanian Christians' claims of the Sonjo culture being more patriarchal than their views must thus be taken with a pinch of salt. Even in Western countries women's emancipation has usually been slower within churches than in the rest of society.

In spite of this, the churches provide the women a space to exercise their autonomy even if the leading positions would be closed for them. The introduction of the churches in the Sonjo area also creates societal movement and tensions where the women can take a more active role than traditionally and negotiate their position. Thus, in the direction of the churches, they can claim that they have no possibilities of changing the traditions concerning the bride price and remarriage - which they would in no way wish to change for the more oppressive "Christian" policies. At the same time, however, the Christian challenge towards the Sonjo traditions is felt and the demand for women's rights is expressed in the church - even if sometimes only for propagandistic purposes. This leads the wenamijie to exercise their power to reduce people's participation in the church activities even if they deny such claims. ${ }^{38}$

However, if one wishes to increase the women's rights, an obvious sphere of action is that of increasing their economic independence and raising their educational standard. However, in general, the increase in equality and women's rights would probably also increase the number of divorces because the women would have better opportunities of leaving unsatisfactory relationships. Were women's voices heard more in the Sonjo churches, the

${ }^{36}$ Danielson 1959: 21; Donovan 2011: 149. Nathan, Eliufoo \& Salema 1952: 7: "Uaminifu katika mambo ya unyumba unakosekana kabisa, na watoto wanaanza uasherati tangu wakiwa wadogo". ("Faithfulness in marriage issues is completely missing, and children begin to fornicate since they are still small.") See also Iversen 1981: 181; 1984: 14-15. However, Lutheran pastor Rong'ola (1976: 60, 71, 72, 77-78), maintains that the Sonjo understanding of marriage is the same as in Christianity because no premarital sexual intercourse is allowed and points out that many marriages between Christians end in divorce while many Sonjo traditionalists remain in their marriages for the rest of their lives. Yet he points out later that divorce is not a strange practice among the Sonjo.

37 On male domination in the African churches, see, for example, Kanyoro 2002: 24.

${ }^{38}$ Women's group interview 08.06.2009: 5-7; cf. Wenamijie group interview 08.06.2009. 
policies formulated in (other) patriarchal cultures (African as well as Western) would need to be reformulated. Only in that case would women's improved position not threaten the moral(istic) teachings of the churches.

\section{Conclusion}

Christian mission among the Sonjo has predominantly been carried out by Tanzanian missionaries. In spite of this, the approach to Sonjo culture has not been any more positive than in much of the criticized Western missionary effort to Africa. After all, the missionaries were generally not of Sonjo background, and one may wonder whether some of the cultural superiority complex had been transmitted from the Western missionaries to the African ones. The encounter of religions has mostly happened as an indirect confrontation in which myths, popular narratives and missionary propaganda have acted as the field of battle.

One of the contested fields is that of gender and sexuality. While Christians purport that their aim is to improve the plight of the oppressed Sonjo women, an analysis of the narratives dealing with gender reveals that the goal often rather seems to be that of destabilizing the role of the apotheosised cultural hero, Ghambageu. Ghambageu serves as the symbol of the rule of (male) traditional leaders. While it is true that Ghambageu is used in many ways to guarantee the male supremacy in Sonjo communities, it is far from self-evident that the removal of all that is related to Ghambageu or Sonjo traditions would actually lead to the improved position of women vis-à-vis men. The use of several of the narratives points rather to another patriarchal rule rather than liberation of the women.

Christian women are in a position of negotiation, in a kind of an interspace between religions where they can make use of the tensions between the two patriarchal systems to create at least some moving space for themselves. This means that while they can wholeheartedly welcome the churches as spaces of self-expression and exercising their autonomy, they can yet support Sonjo traditional bride price and remarriage system which is in an overt conflict with the Tanzanian churches' teachings. They do so partly by claiming not to have a say in the Sonjo society. Their reasoning and active argumentation shows, however, that it is a question of deliberate and conscious pondering of the matter. Resulting from this, one may maintain that the churches improve women's position not only by what they do and teach but perhaps rather much more by just being there as entities creating pockets of resistance against the traditional male hegemony - and at the same time in the ecclesiastic male hegemony because the women make use of their position of negotiation.

Sonjo women's possibilities of improving gender equality seem to have several potential sources: the improvement of women's financial and educational position, the subversive elements in both the Bible and the 
traditional narratives or myths and the tension between patriarchies, traditional and Christian. The use of the Biblical and Sonjo traditional sources for emancipation would presuppose the women's access to these sources. Concerning the Bible, literacy plays the central role, and is improving whereas concerning the Sonjo sources the women would need to get to know the myths and stories. One may expect that the advent of Christianity together with its confrontative tendency towards the Sonjo tradition could contribute to this through the wider circulation of different versions of the myths and popular stories, some of which were meant for a limited audience only.

\section{Sources and literature}

Fieldwork diary (fd.)

Group interviews and discussions with Samunge wenamijie and the traditional priest (Peter Dudui, John Mengo, Ngarasayya, Biobio Nledio [the priest] and Daniel Sadaya) 07.11.2003, 08.11.2003, 07.06.2009 and 08.06.2009.

Group interview with Samunge Christian women 08.06.2009.

Interviews with P1, P2, P3 and P4 07.11.2003 and 08.11.2003. (Names withheld because of the wish of the interviewees for security reasons)

Interview with Rev. Paulo Belelo 07.11.2003, the pastor of the Pentecostal "Church of the 72" in Digodigo.

Interview with Rev. Solomon Isaya 12.06.2005, a former Lutheran missionary to the Sonjo.

Interview with Rev. Gabriel Kimirei 21.06.2005, a retired assistant to the bishop and a frequent visitor to the Sonjo missions.

Interview with Rev. Robert Mallya 07.11.2003, the pastor of the Lutheran church in Samunge.

Interview with Rev. Pius Msuya 05.11.2005, the Roman Catholic priest of Loliondo parish, covering the Sonjo area.

Danielson, Elmer R. 1959. Gateway to Sonjo. Rock Island, IL: Augustana Book Concern.

Donovan, Vincent 2011. The Missionary Letters of Vincent Donovan 1957-1973. Ed. John P. Bowen. Eugene, OR: Pickwick Publications.

Finch, F. G. 1957. Hambageu: Some Additional Notes on the God of the Wasonjo. Tanganyika Notes and Records 47 \& 48: 203-208.

Gray, Robert F. 1963. The Sonjo of Tanganyika: An Anthropological Study on an Irrigation-based Society. Oxford: Oxford University Press.

Gray, Robert F. 1966. Some Parallels in Sonjo and Christian Mythology, in African Systems of Thought, edited by M. Fortes and G. Dieterlen. London: International African Institute/Oxford University Press, 49-61. 
Gray, Robert F. 1968. Sonjo Bride-Price and the Question of African 'Wife Purchase' in Economic Anthropology: Readings in Theory and Analysis, edited by Edward E. LeClair Jr. and Harold K. Schneider. New York: Holt, Rinehart and Winston Inc, 259-282.

Griffiths, J.E.S. 1940. Notes on Land Tenure and Land Rights among the Sonjo of Tanganyika Territory. Tanganyika Notes and Records 9: 15-19.

Iversen, Hans Raun 1984. Case Studies in the Christian Ministry in Ujamaa: Sonjo - the Shortcoming of Approaches to Mission and Boay - the Emergent African Church. (Unpublished paper presented at the Conference Religion, Development and African Identity, Uppsala, 16th to 21st August 1984, Scandinavian Institute of African Studies, Nordic Institute for Missiology and Ecumenical Research.)

Jaeschke, Ernst 1985. Bruno Gutmann, his Life, his Thoughts, and his Work: An Early Attempt at a Theology in an African Context. Makumira Publications 3 \& 4. Erlangen: Verlag der ev.-luth. Mission.

Kanyoro, Musimbi R.A. 2002. Introducing Feminist Cultural Hermeneutics: An African Perspective. Introductions in Feminist Theology. London: Sheffield Academic Press.

Mshana, Bumija Yonazi 1976. Arusha Synod, Tanzania: The Identity of the Church and Its Ministry to the Society. (Unpublished MTh thesis, Wartburg Theological Seminary, Dubuque, Iowa.)

Namjogo, Panuel S. 1996. Historia ya misheni ya sonjo kuanzia mwaka 1948-1950 KKKT Dayosisi Mkoani Arusha. (Unpublished certificate in Theology research paper, Lutheran Theological College Makumira, Usa River, Tanzania.)

Nathan, Eliekana, S.N. Eliufoo and Hilphe Salema 1952. Wasonjo na jinsi walivyopelekewa injili. S.l.: Kanisa la Kilutheri la Tanganyika ya Kaskazini.

Ndula, Simeon, Gabriel N.S. Mavalla \& H.A. Fosbrooke 1955. Hambageu, the God of the Wasonjo. Tanganyika Notes and Records 35: 38-43.

Nyamiti, Charles 1981. The African Sense of God's Motherhood in the Light of Christian Faith. African Ecclesiastic Review 23 (5): 269-274.

Oduyoye, Mercy Amba 1995. Daughters of Anowa: African Women and Patriarchy. Maryknoll, NY: Orbis.

Parsalaw, Joseph Wilson 1999. A History of the Lutheran Church, Diocese in the Arusha Region from 1904 to 1958. Makumira Publications 12. Erlangen: Erlanger Verlag für Mission und Ökumene.

Potkanski, Tomasz 1987. The Sonjo Community in Face of Change. Hemispheres 4: 191-222.

Potkanski, Tomasz and William M. Adams 1998. Water Scarcity, Property Regimes and Irrigation Management in Sonjo, Tanzania. The Journal of Development Studies 34 (4): 86-116.

Rong'ola, Zakayo K.M. 1976. Theologia ya dini ya kitemi (kisonjo) au historia ya dini ya kitemi. (Unpublished certificate of theology research paper, Lutheran Theological College Makumira, Usa River, Tanzania.) 
Schäfer, Alfred 1999. Unsagbare Identität: Das Andere als Grenze in der Selbstthematisierung der Batemi (Sonjo). Berlin: Dietrich Reimer Verlag.

Vähäkangas, Auli 2004. The Crisis of Christian Marriage in Marriage and Family in African Christianity, edited by Andrew A. Kyomo and Sahaya G. Selvam. Nairobi: Acton Publishers, 29-52.

Vähäkangas, Mika 2003. Notes on a Postcolonial Approach to African Church History in Umwege und Weggefährten: Festschrift für Heinrich Balz zum 65. Geburtstag, edited by Jürgen Thiesbonenkamp and Helgard Cochois. Erlangen: Erlanger Verlag für Mission und Ökumene, 476-488.

Vähäkangas, Mika 2008. Between Ghambageu and Jesus: The Encounter between Sonjo Traditional Leaders and Missionary Christianity. Studia missiologica et oecumenica fennica 61. Helsinki: Luther-Agricola-Society.

Watschinger, Herbert ca. 1982. "Don't Give Up Hope" A Life in the Service of the Maasai. s.l.: The Watschinger Family. 